\title{
Evaluation Of Bcl-2 Gene Translocation In NSCLC Lung Cancer Based On Age And Sex Segregation
}

Research Article

Prof Dr. Seyed Saeid, Zamanieh Shahri MD ${ }^{1 *}$, Prof Dr. Sonia Sayyedalhosseini MD ${ }^{1}$

${ }^{1}$ Faculty Member in California Northstate University, CNSU, USA and University Professors in Losrios Community College District, USA.

\section{Abstract}

Objectives: Lung cancer is one of the most dangerous cancers in the world. This study was based on the effect of Bcl-2 (B-cell lymphoma 2) gene family on the regulation of cell death (apoptosis) in the body and cancer progression due to high expression of this gene in patients with Non-small cell lung carcinoma (NSCLC), based on age and sex segregation. The presence of this gene near a strong promoter of the immunoglobulin heavy chain $(\operatorname{IgH})$ on chromosome 14 due to translocation increases the overexpression of this gene.

Methods: This study was performed on 98 paraffin samples taken from Omid Hospital Research and Medical Center (Mashhad Oncology Institute) by using polymerase chain reaction (PCR).

Results: From 98 patients, forty-six patients $(46.9 \%)$ showed translocation of Bcl-2 gene at three chromosomal breakdown points (it means, the translocation of Bcl-2 gene was positive in 46 patients out of 98 patients), that of which forty-six patients, based on gender segregation, $28(60.9 \%)$ were male and $18(39.1 \%)$ were female. Also, based on age, among these 46 people with Positive Bcl-2 translocation, 10 people (21.7\%) were under 55 years old and 36 people $(78.3 \%)$ were over 55 years old. The three chromosomal breakpoints shown in the above patients were associated with a rate of $43 \%$ (20 patients) in the mbr region (Major break-point region), 48\% (22 patients) in the mcr region (minor cluster region), and 9\% (4 patients) in the icr region (intermediate cluster region). The findings of this study suggest treatment by inhibiting this cancer gene.

Conclusion: Suppression of Bcl-2 cancer gene in NSCLC could activate the process of apoptosis in these cancer cells, which may help to find treatment of NSCLC.

Keywords: NSCLC; PCR; mcr; mbr; icr.

\section{Introduction}

The cause of most cancers is the accumulation of mutations in somatic cells. Cell death has a genetic basis and does not occur if this genetic system is disrupted [1].

Cell death is part of the growth program in animal cells. Planned cell death (apoptosis) is important to avoid cancer. All the protein's family found in B-cell lymphoma has a common similar region called the second $\mathrm{Bcl}-2$ identical. These regions are specifically involved in regulating the release of cytochrome $\mathrm{C}$ from mitochondria. Cytochrome $\mathrm{C}$ release is a common event in apoptosis. Cytosolic cytochrome $\mathrm{C}$ with binding to apoptotic factors such as Factor-1 (Apaf-1, Apoptotic protease activating factor 1), dATP/ ATP and procaspase 9 makes the complex of apoptosomes [2].
Positive regulators such as $\mathrm{Bid}, \mathrm{Bic}$, Bak and Bax promote apoptosis and negative regulators like $\mathrm{Bcl}-\mathrm{XL}$ and $\mathrm{Bcl}-2$, stop apoptosis. The function of $\mathrm{Bcl}-2$ is to inhibit the binding of $\mathrm{Bax}$ to the mitochondrial membrane. In fact, the key factor that determines the occurrence of cell apoptosis is the proportion of apoptotic factors to antipoptotic $\mathrm{Bcl}-2$ family proteins [3].

Lung cancer is one of the deadliest cancers in the world. Lung cancers are classified according to their histological type [4]. This classification is important for determining the type of disease management and predicting the outcome of the disease. Lung cancers are malignancies that arise from epithelial tissue. Lung carcinomas are classified under a microscope based on the size and shape of the malignant cells seen by a histopathologist. The two most common categories are non-small cell lung carcinoma

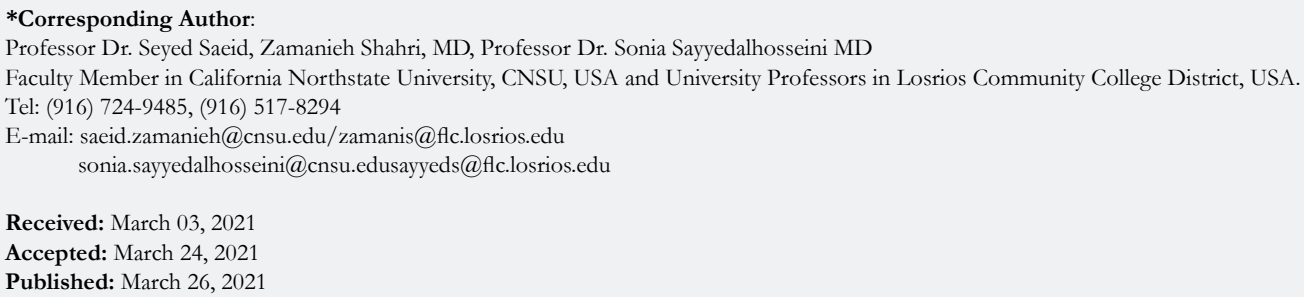

Copyright: Prof Dr. Seyed Saeid, Zamanieh Shahri MD ${ }^{\circ}$ 2021. This is an open-access article distributed under the terms of the Creative Commons Attribution License, which permits unrestricted use, distribution and reproduction in any medium, provided the original author and source are credited. 
and small cell lung carcinoma [5].

Non-small cell lung carcinoma (NSCLC): The three subtypes of this class are adenocarcinoma, squamous cell carcinoma, and large cell lung carcinoma [6]. About $40 \%$ of lung cancers are adenocarcinomas, which usually form in the lateral lung tissue [4]. Most cases of adenocarcinoma are associated with smoking; however, adenocarcinoma is the most common form of lung cancer among people who have smoked less than 100 cigarettes in their lifetime (nonsmokers) [7]. A subtype of adenocarcinoma, the bronchioloalveolar carcinoma, is more common in female neversmokers, and may have a better long-term survival [8]. Squamous cell carcinoma accounts for about $30 \%$ of lung cancers. They typically occur near large airways. A hollow cavity and associated cell death are commonly found in the center of a tumor [4]. About $9 \%$ to $15 \%$ of lung cancers are "large cell carcinomas" [9]. These are so named because the cancer cells are large, with excess cytoplasm, large nuclei, and conspicuous nucleoli [4].

Genetic mutations and epigenetic abnormalities are important factors in lung carcinogenesis. One of the most important factors in the resistance of cancer to treatment is the over-expression of $\mathrm{Bcl}-2$ gene. $\mathrm{Bcl}-2$ proto-oncogene is located on chromosome 18. Placement of this gene adjacent to a strong promoter of immunoglobulin heavy chain $(\mathrm{IgH})$ gene, on chromosome 14 due to translocation, increases the over-expression of this gene [10]. By using flow cytometry and immunohistochemistry a strong link between Bcl-2 gene and $\mathrm{IgH}$ was found [10]. Major break-point region (mbr), in an area with $150 \mathrm{bp}$ (base pairs) long from the 3'untranslated side of exon 3 of $\mathrm{Bcl}-2$ gene and minor cluster region (mcr) approximately $30 \mathrm{~kb}$ (kilo base) downstream of Bcl-2 gene for the length of $500 \mathrm{bp}$ was determined by using PCR method. Intermediate cluster region (icr) and mcr have been identified on exon 3 of Bcl-2 gene [11]. Besides the lung cancer, Bcl-2 gene translocation has also been confirmed in the other cancers such as breast, skin, intestine, prostate, leukemia and lymphoma [12]. It is notable that the naming of this gene was due to the early detection of its displacement in different types of B-cell lymphoma cancers. In most follicular lymphoma, gene translocation of the $t$ $(14: 18)$ (q32, q21) has been detected [13].

\section{Methodology}

The operation of preparing NSCLC lung cancer samples was started by referring to the Oncology Institute and Omid Research and Treatment Center in Mashhad. By referring to the electronic archive of the center, the pathology code of patients with lung cancer was identified. According to the pathology code of each patient, slides prepared from patients were extracted from the archives of the center's patients. All excised slides were examined by a pathologist using a light microscope and NSCLC lung cancer specimens were confirmed by a pathologist at this stage. Also, in this study, the pathologist identified areas of paraffin-embedded tissue containing cancer cells by marker on the slides. Thus, areas of necrosis or healthy cells that were not affected by cancer were excluded from the marked area. The number of selected slides was recorded and the number of blocks containing NSCLC lung cancer tissue was determined using the number of slides. The paraffin-embedded blocks were taken out of the archives of this center, and the marked places on the slides were identified and marked exactly on the blocks. Blocks of these patients were transferred to the laminar air flow cabinet after marking the sampling area. Samples were taken from the labeled area by using Needle 14 and transferred into $2 \mathrm{ml}$ micro tubes that previously had been sterilized by autoclave at $121^{\circ} \mathrm{C}$ for 15 minutes. Then, the samples were transferred to a geneticslaboratory.

DNA extraction from paraffin tissue: Phenol chloroform method was used to extract DNA from paraffin tissue. (14) The steps of DNA extraction in this study were as follows: paraffin separation, tissue hydration, tissue digestion, DNA Clean up, DNA deposition, evaluation of DNA quantity and quality by spectrophotometry.

Primer selection: In this study, primer sequences for the three breakpoints; mbr, mcr, and icr were extracted from the papers. (10) The specificity of the Primers was confirmed on the NCBI (National Center for Biotechnology Information) website in the Primer Blast (Basic Local Alignment Search Tool) section. Primer's sequences are as follows:

1) Primer sequence F: 5'-TCGTTCTCAGTAAGTGAGAGTGC-3' with the length of $23 \mathrm{Mer}$ (mer from Greek word "meros", means part) and GC-content (guanine-cytosine content) of $47.83 \%$ at temperature $62.9^{\circ}$ with product size of $75-135 \mathrm{bp}$ 2) Primer sequence R: 5'-ACCTGAGGAGACGGTGAC-3' with the length of 19 Mer and GC-content of $63.16 \%$ at a temperature of $61.7^{\circ}$ with product size of $75-135 \mathrm{bp}$

3) Primer sequence F: 5'-GAGAGTTGCT'TTACGTGGCC-3' with the length of $20 \mathrm{Mer}$ and GC-content of $45.83 \%$ at temperature of $63.5^{\circ}$ with product size of $200-300 \mathrm{bp}$

4) Primer sequence R: 5'-ACCTGAGGAGACGGTGACC-3' with the length of 19 Mer and GC-content of $63.16 \%$ at a temperature of $61.7^{\circ}$ with a product size of $200-300 \mathrm{bp}$

5) Primer sequence F: 5'-CGCTTGACTCCTT'TACGTGC-3' with a length of $20 \mathrm{Mer}$ and GC-content of $55 \%$ at a temperature of $60.5^{\circ}$ with a product size of $\left.580-630 \mathrm{bp} 6\right)$ Primer sequence R: 5'-ACCTGAGGAGACGGTGACC-3' with a length of 19 Mer and GC-content of $63.16 \%$ at a temperature of $61.7^{\circ}$ with a product size of $580-630 \mathrm{bp}$

The following table consists of the summary of above information.

Table 1. Primer's Characteristics.

\begin{tabular}{|c|c|c|c|c|c|c|}
\hline Primer sequence & $\mathbf{\# 1}$ & $\mathbf{\# ~ 2}$ & $\mathbf{\# ~ 3}$ & $\mathbf{\# ~ 4}$ & $\mathbf{\# ~ 5}$ & $\mathbf{\# ~ 6}$ \\
\hline length & $23 \mathrm{Mer}$ & $19 \mathrm{Mer}$ & $20 \mathrm{Mer}$ & $19 \mathrm{Mer}$ & $20 \mathrm{Mer}$ & $19 \mathrm{Mer}$ \\
\hline Product Size & $75-135$ & $75-135$ & $200-300$ & $200-300$ & $580-630$ & $580-630$ \\
\hline guanine-cytosine content & $47.83 \%$ & $63.16 \%$ & $45.83 \%$ & $63.16 \%$ & $55 \%$ & $63.16 \%$ \\
\hline temperature & $62.9^{\circ}$ & $61.7^{\circ}$ & $63.5^{\circ}$ & $61.7^{\circ}$ & $60.5^{\circ}$ & $61.7^{\circ}$ \\
\hline
\end{tabular}


Polymerase Chain Reaction (PCR): In this study, $12.5 \mu \mathrm{l}$ of Master Mix with the final concentration of $1.5 \mathrm{mM} \mathrm{Mgcl}_{2}$ was used. Its components were: $3 \mathrm{mM} \mathrm{Mgcl}, 0.4 \mathrm{mMs}$ dNTP, 0.2 unit/ $\mu$ l Ampeliqon Taq DNA Polymerase. The PCR reaction according to the values was as follows: Primer R and Primer F, $3 \mu \mathrm{l}$ each, PCR grade Water and DNA Template, and each 500ng.

PCR Schedule: The PCR schedule for the three pairs of primers mbr, mcr and icr was as follows: initial denaturation at $95^{\circ}, 5$ minutes for 1 cycle, denaturation at $95^{\circ}$, annealing at $58^{\circ}$ and extension at $72^{\circ}$ temperature was performed in 1 minute for 35 cycles and finally final extension was performed at $72^{\circ}$ temperatures, 5 minutes for 1 cycle.

Electrophoresis of PCR products: PCR products were stained by using 1\% agarose gel in an electrophoresis device with a voltage of $100 \mathrm{v}$ with ethidium bromide and in a gel documentation device under UV light with a wavelength of $254 \mathrm{~nm}$.

Results of molecular studies: Mbr positive samples were banded at $1 \%$ agarose gel at $300 \mathrm{bp}$ region. In this study, Ladder $100 \mathrm{bp}$ (Fermentas Lot N: 00037552) was used. The positive mcr samples were banded on 1\% agarose at $630 \mathrm{bp}$ region and the icr positive samples were banded on $1 \%$ agarose at 135 bp region.

Results of epidemiological studies: The total number of samples prepared from NSCLC patients was 98, including 56 males and 42 females.

In other words, $42.9 \%$ of the samples belonged to female patients.
And $57.1 \%$ of the samples belonged to male patients.

(0.75: 1$)$

Overall:

Translocation rate in the mcr area:

Translocation rate in the mbr area:

Translocation rate in the icr area:

However, the translocation rate of $\mathrm{Bcl}-2$ gene in women, men and in general, was obtained using the following formulas.

The following diagrams show the occurrence of Bcl-2 gene translocation in the sample population by age and sex.

Statistical analysis of Bcl-2 positive patients: Out of 98 patients, 46 patients $(46.9 \%)$ were $\mathrm{Bcl}-2$ positive, of which $46 \mathrm{pa}$ tients that were $\mathrm{Bcl}-2$ positive, 28 patients $(60.9 \%)$ were male and 18 patients $(39.1 \%)$ were female. Also, among these 46 patients with Bcl-2 positive, 10 patients $(21.7 \%)$ were under 55 years old and 36 patients $(78.3 \%)$ were over 55 years old.

Statistical analysis of Bcl-2 negative patients: Out of 98 patients, 52 patients $(53.1 \%)$ were $\mathrm{Bcl}-2$ negative, of which 52 patients were $\mathrm{Bcl}-2$ negative, 28 patients $(53.8 \%)$ were male and 24 patients $(46.2 \%)$ were female. Also, among these $52 \mathrm{Bcl}-2$ negative patients, 18 patients $(34.6 \%)$ were under 55 years old and 34 patients $(65.4 \%)$ were over 55 years old.

The following tables include the summary of above information.

Figure 1.

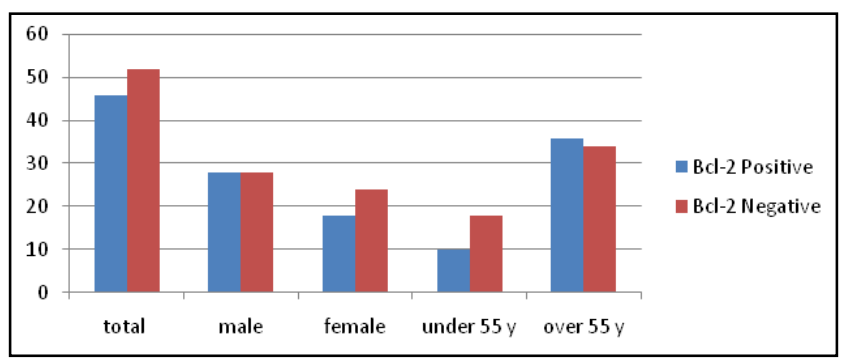

Figure 2.

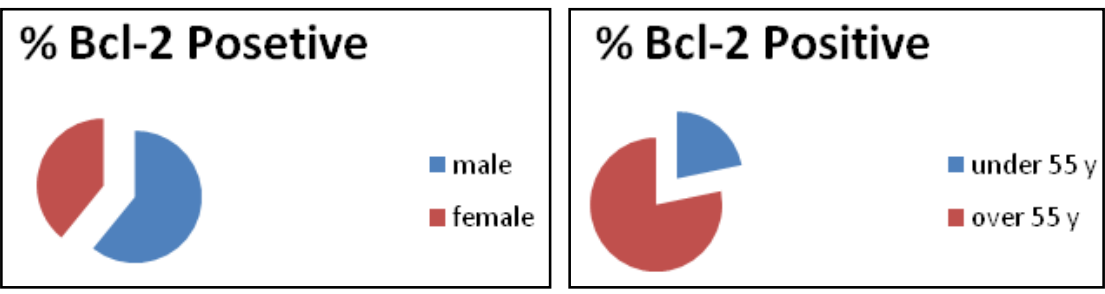

Figure 3.

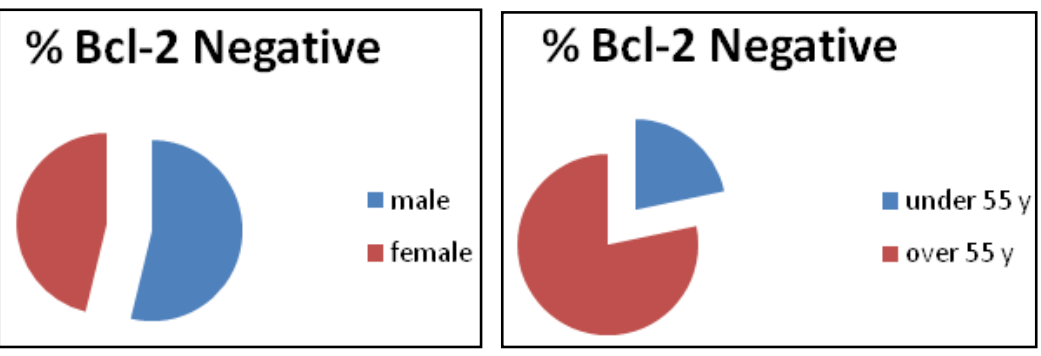


Table 2. Bcl-2 gene translocation in NSCLC lung cancer based on sex segregation.

\begin{tabular}{|c|c|c|}
\hline & Bcl2 Positive (Bcl2+) & Bcl2 Negative (Bcl2-) \\
\hline Paraffin Samples (total: 98$)$ & 46 Sample $(46.9 \%$ of total) & 52 Sample $(53.1 \%$ of total) \\
\hline Paraffin Sample of male patients (male:56) & 28 Sample $(60.9 \%$ of $\mathrm{Bcl} 2+)$ & 28 Sample $(53.8 \%$ of $\mathrm{Bcl} 2-)$ \\
\hline Paraffin Sample of female patients (female:42) & 18 Sample $(39.1 \%$ of $\mathrm{Bcl} 2+)$ & 24 Sample $(46.2 \%$ of $\mathrm{Bcl} 2-)$ \\
\hline
\end{tabular}

Table 3. $B c l-2$ gene translocation in NSCLC lung cancer based on age segregation.

\begin{tabular}{|c|c|c|}
\hline & Bcl-2 Positive & Bcl-2 Negative \\
\hline Paraffin Samples of patients younger than 55 years old (28 samples) & 10 Sample $(21.7 \%$ of Bcl2+) & 18 Sample $(34.6 \%$ of Bcl2 - $)$ \\
\hline Paraffin Samples of patients older than 55 years old (70 samples) & 36 Sample $(78.3 \%$ of Bcl2+) & 34 Sample $(65.4 \%$ of Bcl- $)$ \\
\hline
\end{tabular}

\section{Discussion and Conclusion}

Because the incidence of NSCLC is directly related to age, the incidence of cancer also increases with increasing age of the population. The Bcl-2 protein family plays a role in regulating cell death in the body. Changes in their expression and function contribute to the progression of NSCLC. For this reason, it is a good objective for targeted drugs in the treatment of cancer [15].

In this study out of 98 patients with NSCLC, it was observed that $\mathrm{Bcl}-2$ gene was translocated in 46 patients. Translocation in $\mathrm{Bcl}-2$ gene $\mathrm{t}(14: 18)$ in cancer cells, increases the expression of this gene. The rate of translocation in the mor region was $48 \%$ (22 patients), $43 \%$ in the mbr region (20 patients) and $9 \%$ in the icr region (4 patients). In other studies, lymph node carcinoma has been reported to have $\mathrm{Bcl}-2$ translocation, between 60 and 90 percent and in patients with thyroid cancer, 50 percent. On the other hand, in breast cancer, the translocation of Bcl-2 gene has been reported to be $48 \%$ [16].

Comparison of the results of the present study with other mentioned studies shows that due to the translocation in Bcl-2 gene and its high expression in various cancers, inhibition of the activity of this gene could be a suitable method for targeted treatment of NSCLC. This study is valuable due to the prevalence of NSCLC and the high mortality rate of this disease in relation to targeted treatment. By examining the translocation of Bcl-2 gene in a group of patients with NSCLC, it is possible to identify patients that may be treated with a type of drug that inhibits Bcl-2 gene expression.

\section{References}

[1]. Horvitz HR. Why does programmed cell death, or apoptosis, occur?. Scien- tific American. 1999 Oct. 21; 1.

[2]. Azmi AS, Mohammad RM. Non-peptidic small molecule inhibitors against Bcl-2 for cancer therapy. J Cell Physiol. 2009 Jan; 218(1): 13-21. PMID: 18767026.

[3]. Wolff ME. Burger's medicinal chemistry and drug discovery. American Journal of Therapeutics. 1996 Aug 1;3(8):608.

[4]. Bast Jr RC, Holland JF, Iii EF. Holland-Frei cancer medicine 8. PMPHUSA; 2010

[5]. Kumar V, Abbas AK, Aster JC. Robbins basic pathology e-book. Elsevier Health Sciences; 2017 Mar 8.

[6]. Braunwald E, Fauci AS, Kasper DL, Hauser SL, Longo DL, Jameson JL. Harrison's principles of internal medicine. McGraw Hill; 2001.

[7]. Subramanian J, Govindan R. Lung cancer in never smokers: a review. J Clin Oncol. 2007 Feb 10; 25(5): 561-70. PMID: 17290066.

[8]. Raz DJ, He B, Rosell R, Jablons DM. Bronchioloalveolar carcinoma: a review. Clin Lung Cancer. 2006 Mar;7(5):313-22. doi: 10.3816/CLC.2006.n.012. PMID: 16640802

[9]. Ferri, Fred F. Ferri's Clinical Advisor 2015 E-Book: 5 Books in 1. Elsevier Health Sciences. 2014; 708.

[10]. Albinger-Hegyi A, Hochreutener B, Abdou MT, Hegyi I, Dours-Zimmermann MT, Kurrer MO, et al. High frequency of $t(14 ; 18)$-translocation breakpoints outside of major breakpoint and minor cluster regions in follicular lymphomas: improved polymerase chain reaction protocols for their detection. Am J Pathol. 2002 Mar; 160(3): 823-32. PMID: 11891181.

[11]. Gu K, Chan WC, Hawley RC. Practical detection of t(14;18)(IgH/BCL2) in follicular lymphoma. Arch Pathol Lab Med. 2008 Aug; 132(8): 1355-61. PMID: 18684042 .

[12]. Jalali Nadoushan MR, Davati A, Tavakoli A. Expression of Bcl-2 gene in primary breast cancer and its correlation with some prognostic factors. Journal of Mazandaran University of Medical Sciences. 2007 May 10; 17(58): 30-6.

[13]. Akl H, Vervloessem T, Kiviluoto S, Bittremieux M, Parys JB, De Smedt H, et al. A dual role for the anti-apoptotic Bcl-2 protein in cancer: mitochondria versus endoplasmic reticulum. Biochim Biophys Acta. 2014 Oct; 1843(10): 2240-52. PMID: 24768714.

[14]. Pikor LA, Enfield KS, Cameron H, Lam WL. DNA extraction from paraffin embedded material for genetic and epigenetic analyses. J Vis Exp. $2011 \mathrm{Mar}$ 26; (49): 2763. PMID: 21490570.

[15]. Yip KW, Reed JC. Bcl-2 family proteins and cancer. Oncogene. 2008 Oct 27; 27(50): 6398-406. PMID: 18955968.

[16]. Kirkin V, Joos S, Zörnig M. The role of Bcl-2 family members in tumorigenesis. Biochim Biophys Acta. 2004 Mar 1; 1644(2-3): 229-49. PMID: 14996506. 